\title{
A theoretical framework on network's dynamics for precision agriculture technologies adoption
}

\author{
Um referencial teórico sobre a dinâmica de redes para adoção de \\ tecnologias de agricultura de precisão
}

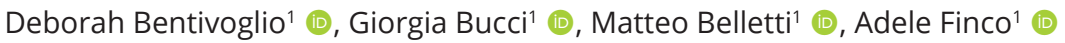

1'Dipartimento di Scienze Agrarie, Alimentari e Ambientali (D3A), Università Politecnica delle Marche (UNIVPM), Ancona (AN), Italia. E-mails: d.bentivoglio@staff.univpm.it; g.bucci@pm.univpm.it; m.bellettini@univpm.it; a.finco@univpm.it

\begin{abstract}
How to cite: Bentivoglio, D., Bucci, G., Belletti, M., \& Finco, A. (2022). A theoretical framework on network's dynamics for precision agriculture technologies adoption. Revista de Economia e Sociologia Rural, 60(4), e245721. https://doi. org/10.1590/1806-9479.2021.245721
\end{abstract}

\begin{abstract}
Recently, the agricultural sector has had to face several challenges related to the innovation process, the most significant of which seems to be that of its digital transformation. As a consequence, the issue of digital technology adoption is becoming of important scientific interest due to its potential impact on products, services, processes, and new business models. In general, the adoption behavior can be indirectly explained by studying factors that lead a firm to innovate; among these factors, the literature emphasizes the function of networks. The objective of the paper is to investigate the role of networks as key drivers of precision agriculture technologies adoption. To achieve this goal, qualitative research was developed by using 8 case studies recollected among that few Italian farms which can be defined as innovative for having already experienced precision agriculture. Results show that only a few farms can develop and manage innovations internally; success often requires cooperation between individual actors and organizations. Finally, the paper provides some practical advice and a set of propositions for those farms that are trying to achieve digital technological innovations.
\end{abstract}

Keywords: precision agriculture, technology adoption, networks, qualitative research, theoretical framework.

Resumo: Nos últimos anos, o setor agrícola tem enfrentado diversos desafios relacionados com o processo de inovação, sendo que o mais significativo parece ser o da sua transformação digital. Por consequência, a questão da adoção da tecnologia digital está se tornando de importante interesse científico e atraindo a atenção de uma série de pesquisadores devido ao seu impacto potencial em produtos, serviços, processos e novos modelos de negócios. Em geral, o comportamento de adoção pode ser explicado indiretamente pelo estudo de fatores que levam uma empresa a inovar; entre esses fatores, a literatura enfatiza a função das redes. O objetivo do artigo é investigar o papel das redes como principais impulsionadoras da adoção de tecnologias de agricultura de precisão. Para atingir este objetivo, foi desenvolvida uma pesquisa qualitativa a partir de 8 estudos de caso representados por fazendas italianas, com experiência em agricultura de precisão. Os resultados mostram que apenas algumas fazendas têm a capacidade de desenvolver e gerenciar inovações internamente; o sucesso frequentemente requer cooperação entre atores individuais e organizações. Finalmente, o artigo fornece alguns conselhos práticos e um conjunto de propostas para as fazendas que estão tentando alcançar inovações tecnológicas digitais.

Palavras-chave: agricultura de precisão, adoção de tecnologia, redes, pesquisa qualitativa, quadro teórico.

\section{Introduction}

As the innovation process is a strategic factor and an important driver of economic growth and productivity, the capacity to innovate is a necessary condition, in particular for those firms seeking to create and maintain a competitive position in the global market (Cho \& Pucik, 2005). 
Innovation is a very broad concept and has been studied extensively from many points of view (Touzard et al., 2015). The major point of reference for innovation concepts is Schumpeter's (1982) original notion of innovation (1982) which refers to the classical view that is based on a sequence of phases involving the creation of ideas, invention, research and development, application, and diffusion. However, in contrast to the classical view, referring to observations in practice, Schumpeter argues that innovation emerges in a complex iterative process where communication, learning, and social interaction play important roles. Consequently, innovation is not seen as a mere technical issue but rather "the result of a process made up of many steps and gathering many individuals, organizations and institutions along the way" (Laperche, 2012).

In fact, the innovation process is not solely internal one. Thus, for the firm, innovation is always the result of interactions and feedback between individuals, organizations, and institutions involved in the process (Rosenberg \& Landau, 1986). In other words, while acknowledging the role of technology in shaping economic progress, the innovation process would be the result of network dynamics at an institutional and organizational level, which are therefore interesting to explore (Wendschlag, 2009).

This supports the view on networking as a suitable tool for innovation support. Indeed, many studies on innovation accentuate the fact that innovation is a systemic process in which firms interact and collaborate with a variety of networks (Ritter \& Gemünden, 2003; Pittaway et al., 2004; Chesbrough, 2012). In addition, the innovation literature has shown how firms capable of creating networks are more innovative than "isolated" ones. Firms participate in different networks to spread the risk and uncertainty involved in the innovation processes, shorten innovation time, reduce costs, and access external resources upon which innovations may potentially be built (Cantner \& Graf, 2011; Li et al. 2018).

However, according to Nieto \& Santamaría (2007), critical issues such as the selection of partners and what type of networks favor innovation still require further research. Previous studies have demonstrated that farms do pursue innovation (Knudsen, 2007; Fortuin \& Omta, 2009), albeit to a lesser extent compared to firms in other sectors. Consequently, networks become especially important for those farms because, as is known, these are usually restricted from a dimensional point of view. In addition, due to the close interactions and dependencies between farms and the actors in the food supply chain, networks become a baseline requirement for any successful initiatives towards innovation.

Today, among the various innovations which interest the agriculture sector, precision agriculture technology has emerged as an important phenomenon that has attracted the attention of several scholars and practitioners, principally due to its potential impact on products, services, processes, and business models (Kosior, 2018; Bucci et al., 2019).

The main precision agriculture technologies include information-gathering tools (such as yield monitors), targeted soil sampling and remote sensing tools, variable rate technology, and guidance systems (such as light bars and auto-steer equipment). Precision Agriculture (PA) is conceptualized by a system approach to re-organize the total system of agriculture towards a low-input, high-efficiency, sustainable agriculture (Shibusawa, 1998; Lindblom et al., 2017). This new approach mainly benefits from the emergence and convergence of several digital technologies.

Thus, PA might change farming into digital farming, assuring the optimization of the management of resources throughout the farm system and making the value chain more traceable and coordinated at the deepest level. Hence, the adoption of innovative practices as well as the role that networks play in it deserves more attention. On this premise, this 
paper aims to investigate the role of various networks in the process of precision agriculture technologies adoption in the agricultural sector addressing the following research questions:

- Q1: How do different types of relationships favor the adoption of precision agriculture technologies?

- Q2: What types of actors favor this process?

- Q3: How networks play a role in supporting the digital technological process?

Answering these questions, the article wants to formulate a theoretical framework on the adoption of innovations in agriculture.

We address these research questions through a qualitative analysis of 8 of the most innovative farms, with a great experience in PA, located in the center of Italy. In particular, we use a qualitative content analysis methodology to examine the data obtained by carrying out semi-structured interviews. Since qualitative methods are largely inductive, they are particularly suitable to approach to develop hypotheses for further research steps, helping in providing context and foundation for quantitative analyses (Pignatti et al., 2015).

To accomplish the above-mentioned objectives, we have structured this work into five sections, including the current introduction. In Section 2, we present a framework for reading the agricultural innovation process based on the current political and social contest. Section 3 presents a literature review on firms' innovation adoption behavior, focusing on the role of networks. In Section 4, we describe the method employed in our research. The main results of our research are outlined in Section 5. The final section includes our conclusions and the implications of the study.

\section{The innovation process in the agricultural sector}

Defining the innovation process in the agricultural sector is more complicated than for other sectors. Indeed, literature concerning the innovation process and its underpinning drivers in this sector is very fragmented due to several additional elements that affect the development of the innovation process (Shikida et al., 2010; Souza Filho et al., 2011; Avolio et al., 2014).

That is why, especially in this domain, it is very difficult to generalize the discourse about innovation diffusion and development (Crossan \& Apaydin, 2010). We could simply and comfortably define innovations in agriculture as new methods, customs or devices used to perform new tasks. However, given the current social and political context referring, in particular, to the challenge of climate change and the environmental crisis, we support the idea that innovation in this sector can no longer be fully understood as a mere technological issue but rather (and perhaps first of all) as an organizational, institutional, and cultural one. Moreover, to fully capture the essence of innovation across a wide range of issues, the purpose of innovation - and what it is or should be - can no longer be taken for granted; the same goes for the dynamics according to which innovation has to be first exogenously generated and then passively adopted.

Therefore, let us begin to discuss the theme of innovation in agriculture by breaking the innovation issue down into the following questions: i) What is the purpose (or incentive) from which innovation in agriculture eventually arises? (WHY innovate?) ii) How does innovation unfold? (HOW can we innovate?).

The first question is only apparently straightforward but is actually quite challenging to answer. The core objective of innovation in agriculture has always been that of productivity enhancement and cost-effectiveness at a production process level. A critical issue implicit in 
the innovation process lies in the fact that, typically, the adoption of new technology is a slow diffusion process (Griliches, 1957). This dynamic implies that the few early adopters (pioneers) benefit from the innovation effect on productivity and efficiency.

Nevertheless, given the traditionally inelastic agriculture demand curve when, later, the majority of producers adopt it, the new technology determines an increase of the farm output and a more than proportional decrease in market prices. As a result, the farms that are late adopters typically face critical conditions: high production costs due to the innovation adoption and decreasing sales prices (Barnes et al. 2019). This is Cochrane's (1958) famous "treadmill effect": in the presence of technical progress, any farmer who does not quickly adopt it is threatened with declining profit. This scenario puts pressure on farm managers to deal with the difficulties arising from these innovation dynamics; early adopters are therefore likely to possess superior managerial skills (Chavas, 2001).

This means that innovation and technical change tend to favor good managers and this "managerial bias" has important implications. For example, one of these implications is that the benefits from technical change can vary greatly across firms within a sector. Moreover, as is known, farmers are generally exposed to a supply chain dominated by monopolies both upstream and downstream of the agricultural firm.

Consequently, in this context, how can innovation unfold? Despite the potential market risk connected to the widespread adoption of cost-saving and yield-increasing innovations, we can say that farmers would be willing to innovate to some extent if the policies could effectively support the introduction of an innovation. However, at the European level, there are still no specific measures that support the adoption of an innovation in the agricultural sector, but there are generic measures to boost the innovation of this sector. For instance, several Common Agricultural Policy (CAP) objectives have been introduced for innovation in agriculture. Within the new Rural Development Policy programming period, the European Innovation Partnerships (EIPs), the Operational Groups (OGs), and different technological clusters became new ways to foster innovation (Finco et al., 2018), giving proof of applying the "Multi-Actor Approach" (MAA)".

Developed under Horizon 2020, MAA puts into practice the "interactive innovation model", which allow fostering the development of research into practical applications and the creation of new ideas thanks to interactions between different actors ("cross-fertilization") and the sharing of knowledge (Ingram et al., 2018; Knierim et al., 2019). Thus, the set of motivations or incentives that push the innovation process in the agriculture sector is not as straightforward as it seemed at first sight. To understand why farmers, innovate, it becomes crucial to identify the key drivers that can affect the innovation adoption process.

In particular, as we will discuss later, the presence of an adequate context from which an innovation process may originate can be found in the case in which producers (both horizontally and vertically along the supply chain) are systemically connected, thereby forming a collaborative environment that we could define as a network. According to Rogers (1971) adoption of a new idea is caused by human interaction through interpersonal networks. If the initial adopter of an innovation discusses it with two members of a given social system, and these two become adopters who pass the innovation along to two peers, and so on, the resulting distribution follows a binomial expansion.

\footnotetext{
The authors wish to thank the members of the Operational Group (OP) S.A.T. (SMART AGRICULTURE TEAM) - Precision agriculture: reduction of the environmental impact of production systems (ID N²9000) and the Operational Group (OP) SMART VITIS - Intelligent and Sustainable Viticulture (ID N² 290089) - financed by RDP Marche 2014/2020, Submeasure 16.1 - for the support provided in the study.
} 


\section{The role of networks in the innovation adoption process: a literature review}

According to the literature, we can say that innovation adoption could be attributed to different factors. Indeed, the various factors and determinants considered important for firms to innovate have been extensively analyzed by the literature (Mohr, 1969; Majumdar, 1995; Becheikh et al., 2006; Dziallas \& Blind, 2019). Most of the literature, through quantitative studies, identify internal and external factors that lead firms to innovate (Avermaete et al., 2003; Cirani \& Moraes, 2010; Baregheh et al., 2012; Pérez-Castillo et al., 2013; Bolfe et al., 2020; Bucci et al., 2020; Chen, 2020).

Internal factors are linked to the various features of the organizations, such as: business size, sales of the firm, the experience age of the company, number of employees; the firm's turnover; the characteristics of the entrepreneur, and R\&D activities. On the other hand, external factors are related to the firm's environment. These external factors are linked to the socio-economic, institutional, administrative, and physical contexts in which the firm operates. The external factors are: the existence of public funding, the presence of agglomeration economies, networks, relationships, market orientation, policies, and external organizations. Among the aforementioned factors, the literature emphasizes that networks play an important role and are a necessary condition for the adoption of innovations (Katz \& Shapiro, 1986; Warriner \& Moul, 1992; Robertson et al., 1996; Ritter \& Gemünden, 2004; Bandiera \& Rasul, 2006; Zeng et al., 2010).

In particular, different authors highlight that networks are positively associated with preadoption (Rogers, 2003; Glanz et al., 2008) and adoption (Frambach \& Schillewaert, 2002; Berta et al., 2005) of an innovation. In addition, a growing part of the literature has pointed out that the adoption of innovation is a collaborative phenomenon that results from various interactions among different actors (Hagedoorn, 2002; Hakansson, 2015). In this respect, single firms rarely innovate alone, they tend to band together in teams and coalitions based on 'swift trust'. In fact, we can define a network as a set of relationships between the firm and business partners, suppliers, customers, professional and trade associations, technology centers, service providers, clusters, research organizations (such as universities), employees, friends, consultants, and many others.

These networks may not only be business relationships but also involve personal relationships. Thus, networks are formed by heterogeneous groups of actors. This section aims to summarize and review the importance of networks in the adoption of an innovation in firms, focusing on the theoretical and empirical studies that are relevant to support this aspect. According to Corsaro et al., (2012), two elements seem to characterize the importance of networks: the first element is the multiplicity of outcomes or advantages that could derive from collaboration and the second is the variety and diversity of actors involved.

Looking at the first aspect, a body of literature argues that networks enable firms to overcome the limited resources (both financial and human) needed for the innovation process (De Massis et al., 2018). On one side, the availability of funds and budgeting for innovation-related activities all seem to have a positive and significant effect on innovation. Financial autonomy and profitability increase the probability of carrying out investments, doing in-house R\&D, and generating innovations (Geiger \& Cashen, 2002; Beneito, 2003).

On the other side, human resources, enable companies to have a qualified and motivated workforce capable of creating new technologies and absorbing those developed externally (Hoffman et al. 1998). The network, therefore, provides access to complementary resources which are not easily available internally. Secondly, different studies show that 
the network is useful for overcoming the internal lack of knowledge and information relating to the firm's decisions concerning the innovation process (Bullinger et al., 2004; Phelps et al., 2012).

Thus, through networks, knowledge is not only transferred but also created. However, to create new knowledge the diverse sources also need to be integrated within the firms. Another important role that the literature recognizes to the networks is their capacity to enhance the innovation performance and productivity of firms (Lin \& Lin, 2016).

Firms use their network relationships to facilitate their international process (Narula, 2004; Ojala, 2009) and to speed up finding new business and market opportunities (Ibeh \& Kasem, 2011). An increasing number of studies show that networks are important for firms to minimize the risks and uncertainty associated with innovation. Networks are usually important for ensuring co-investment. Such investment enables risk to be spread and usually leads to higher-quality investments and larger levels of investment for individual firms. Specifically, all these lacks that networks can solve, are strongly present in small-medium-sized enterprises (SMEs) respect large firms (Edwards et al. 2005).

More in detail, large companies have more resources to innovate and support risky activities than in SMEs and, at the same time, large firms can benefit from economies of scale in R\&D, production, and marketing (Damanpour, 1992; Tsai, 2001; Stock et al., 2002). Indeed, different studies underlined that SMEs do not have the internal infrastructure to support sufficient interaction, or the knowledge and financial capital necessary for a successful innovation process (Jarillo, 1989; Nooteboom, 1994; Desouza \& Awazu, 2006; Van de Vrande et al., 2009; Durst et al., 2013).

In addition, within SMEs, top managers play a unique position in shaping organizational strategies, processes, and outcomes affecting the adoption of innovation (Hambrick \& Mason, 1984; Geletkanycz \& Hambrick, 1997). Therefore, due to the important role of managers in the decision-making process, the managerial networks, which refer to the connections of top managers with external actors, are critical for innovation adoption (Kraft \& Bausch, 2018).

Compared to the other industries, the creation of networks is even more complex in small-scale farms in which farmers are not perceived as real entrepreneurs as in non-farm business (Wolf et al., 2007). Farms may have been owned or managed within the same family for generations. This ownership/management role has militated against farmers from being entrepreneurial (Kahan, 2013). However, the role of the farmer in Europe is changing, as farmers have to develop new skills to be competitive. In a word, they need to become more entrepreneurial (McElwee, 2006). For small-scale farmers to become managers they need to be innovative and forward-looking.

Relating to the second aspect, the literature stressed that different actors involved in the network of a firm provide different types of information and knowledge that can influence the process of innovation adoption (De Faria et al., 2010; Mors, 2010). This is mainly because different stakeholders often have contradicting priorities, goals, and views. Thus, researchers tended to investigate the impact of any single actor within a network on innovation adoption by firms. According to Lasagni (2012), firms could invite users or customers to participate in the innovation process directly to quickly obtain new product definitions. At the same time, several studies have documented that universities and other research institutions can be important partners that bring new scientific and technological knowledge into the firm (Bozeman, 2000; Drejer \& Jørgensen, 2005). 
Finally, it is important to underline that in addition to the positive benefits, networks can also have negative consequences on innovation: the costs of maintaining additional ties reduced information benefits, or information overload (Ahuja, 2000).

\section{Materials and methods}

While the process of technology adoption by farmers has been widely studied through quantitative research (Adnan et al., 2019; Michels et al., 2019), over the last two decades there has been an increasing interest in the use of a more qualitative approach. Qualitative content analysis is one of the numerous qualitative approaches used to analyze text data.

The goal of content analysis is to provide knowledge and understanding of the phenomenon under study since it is considered the study of recorded human communications (Babbie, 2001) with a "systematic, objective, quantitative analysis of message characteristics" (Neuendorf, 2002). The flexibility of the methodology makes it particularly appropriate for Social Science research, given that, according to Bates (1999), content analysis is focused of is the "study of gathering, organizing, storing, retrieving, and dissemination of information".

In comparison to sociology, the use of qualitative research strategies is less developed in agricultural economics, even if the social aspect of agricultural economics can contribute new and useful perspectives to the field of a qualitative study (Bitsch \& Hogberg, 2005). Content analysis can be both quantitative (focused on counting and measuring) and qualitative (focused on interpreting and understanding). In their work, Hsieh \& Shannon (2005), summarized three distinct approaches for qualitative content analysis: conventional, directed, or summative. The major differences depend on the coding schemes and the origins of codes.

Conventional content analysis implies a direct approach in which those coding categories are derived directly from the text data. The directed approach starts with a priori with the study of the theory or relevant research findings for the initial codes. Finally, the summative content analysis needs the counting and comparisons of keywords and after that, the interpretation of the context is needed.

For this study, we applied the Conventional Content Analysis, generally used with a study design whose aim is to describe an emergent phenomenon, such as the diffusion of technology through a network. This type of design is usually appropriate when an existing theory or research literature on a phenomenon is limited.

To finalize the conventional approach, we avoid using preconceived categories (Kondracki et al., 2002), instead of allowing the categories and names for categories to emerge from the data. Based on the Theory of the Diffusion of Innovations by Rogers (1962) the choice of the sample is concentrated on the innovators and early adopters categories among Italian farmers. The process of adoption over time is typically explained as a classical normal distribution of the "bell curve".

The model includes five types of users. The first group of users are the "Innovators": they are Technology Enthusiasts. These innovators usually try technological products even before they are released to the market. Then, it comes the "Early Adopters", also referred to as Visionaries, since they are the primary users who buy the new product, as soon because it comes out on the market. Next, comes the Early Majority: this group is "Pragmatists", before choosing to adopt a particular technology, they wait to see its effects on those who adopt it before them. Then, the Late Majority Group, also known as "Conservatives". They usually wait to adopt new technology after the majority of other consumers have already done so. Finally, the Laggard 
group is composed of "Skeptics" users since they are the most traditional among consumers, even considered technology-averse. This group is typically made up of older consumers that decide to purchase technology once there is an even newer technology making its way through the adoption lifecycle.

According to Moore (1995), the theory also suggests five characteristics of an innovation, which may affect its rate of adoption: I) relative advantage; II) compatibility; III) complexity; IV) trialability and $V$ ) observability.

The adoption of precision agriculture among farmers affects all these aspects. This has led Moore to propose a "chasm" in high-technology adoption between early adopters and the majority, risking a fatal stalling of the adoption process.

Several studies suggest that network activities and collaboration with innovation practitioners are correlated with overcoming the chasm. From this perspective, innovations can be developed within a dynamic and co-evolutionary process, in which the actors of the network are the key to creating and maintaining innovation processes.

According to Knierim et al. (2019), farmers included in a range in innovation processes, have been revealed as strategic partners to dealing with the uncertainties associated with digital technologies. For these reasons, our study is qualitative and exploratory in nature, and proposes the use of the network from the farmer's perspective, as a tool to cross the chasm. Based on these premises, a qualitative content analysis method was applied to highlight how an organized network can support the adoption of new technologies among farmers, by analyzing the good practices related to digitalization, promoted by the interviewees.

For the design of the content analysis, we followed the approach designed by Elo and Kyngäs (2008) which proposed three general steps for content analysis: (1) preparation (2) organizing, and (3) reporting, and to guarantee the trustworthiness in all these three steps, we followed the checklist for researchers, proposed by Elo et al., (2014). Following the checklist, during the preparation phase, attention was paid to the sampling method and the unit of analysis. The sample was not selected randomly. Purposive sampling is the most commonly used method in content analysis. This type of sampling is suitable for qualitative studies where the researcher is interested to collect information from those who have the best knowledge concerning the research topic, which is farms that have experience in precision farming and have a network that fosters innovation.

Thus, the criteria used to select the participants was based on the experience of the participants in Precision Agriculture Technologies and the complexity of the technology itself.

The process of sampling concluded when the saturation point was achieved, a condition in which a newly added unit of analysis ( $\mathrm{a}$ farm) did not provide any additional relevant information. Saturation is used in qualitative research as a criterion for discontinuing data collection and/ or analysis. The saturation point was reached with 8 interviews. Although the number of interviews may seem low for this research, it is important to point out that the sample size is dictated by theoretical saturation. In addition, the sample size is in line with several qualitative studies on digital innovation applied in different contexts, that use samples that varies from 3 up to 14 participants (Eze et al., 2011; Almeida et al., 2017; Cheong \& Mohammed-Baksh, 2019; Kashada et al., 2020). Table 1 shows the farm's characteristics of the sample. 
Table 1 - Sample

\begin{tabular}{|c|c|c|c|c|}
\hline Sample & Region & $\begin{array}{l}\text { Farming } \\
\text { system }\end{array}$ & $\begin{array}{l}\text { Year of } \\
\text { experience } \\
\text { in PA }\end{array}$ & Type of Technology adopted \\
\hline Farm 1 & Marche & Milk & 10 & Robotic milking system \\
\hline Farm 2 & Marche & $\begin{array}{l}\text { Cereals, Fruit, } \\
\text { and vegetables }\end{array}$ & 20 & $\begin{array}{c}\text { Tractors with ISOBUS, Rate of } \\
\text { variable applications, prescription } \\
\text { maps, drones, detection of soil } \\
\text { resistivity, DSS }\end{array}$ \\
\hline Farm 3 & $\begin{array}{l}\text { Emilia } \\
\text { Romagna }\end{array}$ & Cereals & 12 & $\begin{array}{c}\text { Tractors with ISOBUS and Rate of } \\
\text { Variable applications }\end{array}$ \\
\hline Farm 4 & $\begin{array}{l}\text { Emilia } \\
\text { Romagna }\end{array}$ & Cereals & 15 & $\begin{array}{l}\text { Tractors with ISOBUS, variable } \\
\text { rate fertilizer spreader, machine } \\
\text { for weeding and treatment with } \\
\text { variable dosage distribution }\end{array}$ \\
\hline Farm 5 & $\begin{array}{l}\text { Emilia } \\
\text { Romagna }\end{array}$ & $\begin{array}{l}\text { Cereals, Fruit, } \\
\text { and vegetables }\end{array}$ & 5 & $\begin{array}{c}\text { Tractors with ISOBUS, Rate of } \\
\text { variable applications, prescription } \\
\text { maps, drones, detection of soil } \\
\text { resistivity, DSS }\end{array}$ \\
\hline Farm 6 & Lazio & $\begin{array}{l}\text { Milk, cereals, } \\
\text { fruits and } \\
\text { vegetables, } \\
\text { Grape }\end{array}$ & 4 & $\begin{array}{l}\text { Tractors with ISOBUS, Prescription } \\
\text { maps, Near Infrared sensors }\end{array}$ \\
\hline Farm 7 & Toscana & Grape and Oil & 15 & $\begin{array}{c}\text { Telemetry on company tractors, } \\
\text { variable dose machinery, use } \\
\text { of prescription maps, detection } \\
\text { of soil resistivity, management } \\
\text { platforms for monitoring all } \\
\text { processes }\end{array}$ \\
\hline Farm 8 & Toscana & $\begin{array}{l}\text { Grape, Fruit, } \\
\text { and vegetables }\end{array}$ & 15 & $\begin{array}{c}\text { Tractors with ISOBUS, Rate of } \\
\text { variable applications, prescription } \\
\text { maps }\end{array}$ \\
\hline
\end{tabular}

Precision agriculture technologies are a sub-group of digital technologies including the Internet, mobile technologies and devices, data analytics, artificial intelligence, digitally-delivered services, and apps that are changing the whole agriculture and the food system. Some examples of technologies at a different level of the agri-food value chain are: farm machinery automation allows fine-tuning of inputs and reduces demand for manual labor; remote satellite data and sensors improve the accuracy and reduce the cost inputs; and traceability technologies and digital logistics services offer the potential to streamline agri-food supply chains, while also providing trusted information for the final consumers.

Based on these premises in-depth, face-to-face interviews were conducted with the managers of farms. The interviews were approached with a questionnaire related to the use of the networks in the process of technology adoption. The questionnaire is divided into two parts. The first part aims to collect the general information of the farm; the second, includes a set of questions, organized in 3 sub-sections, as follows: (i) Type of networks in which the farmer is involved; (ii) Type of actions within the networks; (iii) Benefits from the networks.

In line with the literature, we decide to interview this figure because managers play a unique position in shaping organizational strategies, processes, and outcomes affecting the adoption of innovation. As a consequence, the managerial networks, which refer to the connections of managers with external actors, are crucial for innovation adoption. All interviews were conducted in person, except for 2 of them, which were done on Skype. The interviews typically lasted 60-90 minutes and were tape recorded and transcribed verbatim. Then, the utilization 
of data triangulation determined an all-inclusive knowledge and a clear understanding of participants (Yin, 1989).

The phase of organization implied the transcription of the interviews and their import into ATLAS.ti., a qualitative data analysis tool that allows organizing and sorting the transcribed interviews into themes, or 'coded'. The coding process allowed all the relevant data sources related to the use of the network as a means to reach technological innovation within the farm to be examined. Two researchers performed the analysis to increase the comprehensivity and provide sound interpretation of the data (Burla et al., 2008), and both researchers were trained in conducting in-depth interviews and analyzing qualitative data. The main results were organized firstly in codes, derived from the quotes directly expressed by the respondents. This data was then organized thematically by creating consistent groups of categories.

Finally, for the phase of reporting, we reported systematically and logically, by grouping the categories into three main themes which allow the researchers to interpret and explain the phenomenon.

\section{Results and discussion}

Before starting the content analysis, we performed a word cloud used as a graphical representation of the answer of the interviewees (Figure 1).

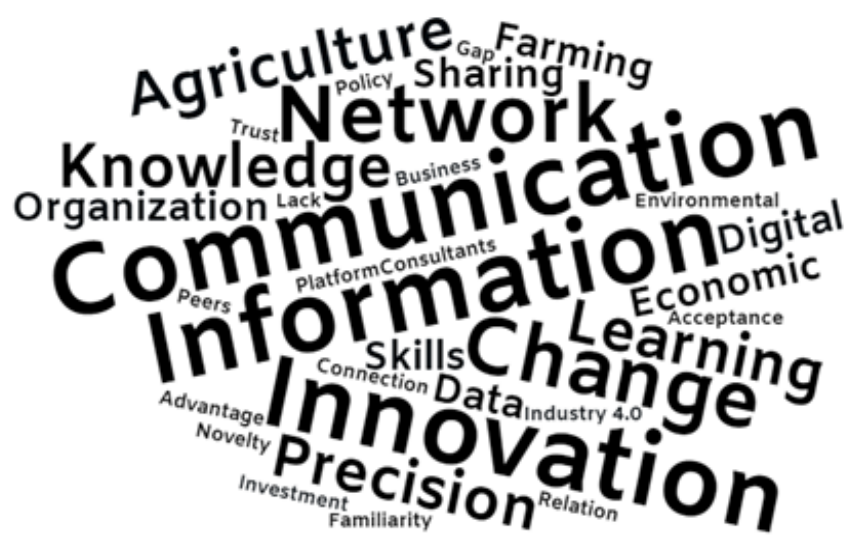

Figure 1 - Word cloud summarizing the most frequent words among interviewees

In particular, in qualitative research, the word clouds are useful as initial screening tools for qualitative research data (DePaolo \& Wilkinson, 2014). By analyzing the resulting word clouds, we were able to determine that farmers have more frequently resorted to words such as "Communication", "Information", "Network", "Change" and "Precision" during the interview.

In addition, the innovative characteristics, the pioneer vision, and the experiences in precision farming technologies usage of the selected farm was confirmed by the interviewees, which considered themselves innovators and early adopters:

\footnotetext{
- "I have been attracted by everything that is innovative, also in agriculture. My father and my uncle transmitted their passion to me thus allowing me to introduce technological innovations into the farm, thus realizing the important contribution that I was making within the farm. Honestly, I can say that on the regional level there is no such innovative reality like ours" (Farm 2);
} 
- "We started in 2016 with basic precision farming technologies. From that moment on, we have never stopped innovating, continuing to invest in the latest technologies. Here in Italy, we think we are ahead with these technologies, but in the United States, for example, these technologies have already been used for 20 years" (Farm 6).

Before describing all the major themes that emerged from the data analysis, we want to present the answers to the three proposed research questions, by using the most representative quotes of participants, to increase the credibility of the study findings (Graneheim \& Lundman, 2004).

Q1: How do different types of relationships favor the adoption of precision agriculture technologies?

- "But in agriculture more than in other sectors the human relationship is still very important. This is why it is important to have a direct and constant exchange with consultants, who always keep us updated on the latest news" (Farm 5);

\begin{abstract}
- "Political support is still not enough. We have participated in several founded project calls, but on the one hand, we have been discouraged by the constraints for participation and on the other, by the bureaucracy that slows down the innovation process. To make you understand: once we participated in a project called for the technological change in agriculture, proposing certain technologies within that project. We had the results of the call after two years, and by that point, the technologies we proposed within that project had become outdated" (Farm 7).
\end{abstract}

\title{
Q2: What types of actors favor this process?
}

- "Being in close contact with technology providers absolutely has advantages. First of all, if something breaks, we are guaranteed quick service. We are also the first to be informed about the latest innovation available on the market, and then, if we are lucky they also let us test it as a pilot site" (Farm2)

- "Technological innovation is often stimulated by University, which is often our partner in funded projects" (Farm 8)

- "It often occurs that, farms that want to start investing in precision agriculture from zero, turn to us asking for some advice on which technologies to buy. We are always open to discussion, especially with those companies that do not believe in the efficiency of precision agriculture" (Farm5)

\section{Q3: How networks play a role in supporting the digital technological process?}

- "I like going to fairs and events because it can always happen to meet other farmers that do the same thing you do, but in a better way and therefore you can always learn new things thanks to the positive example from those who are better than you" (Farm 1);

\footnotetext{
- "For our company, it is essential to have a network of companies with characteristics similar to ours, to exchange views and opinions on technology. Since we are still few (with these technological characteristics), it is essential to confront each other" (Farm 4);
}

\footnotetext{
- "We are an agricultural cooperative so we have purchased the necessary equipment that we use for working the land of all the members of the cooperative. Thanks to this change, of course, we have contributed to making farmers aware of this new management possibility (AP management)"(Farm 3).
}

By using the full set of codes and categories, we developed the data structure in Figure 2, which allowed us to derive the main theoretical theme that explains how the network can be used in the process of precision agriculture adoption. In particular, as information about new technologies is a necessary condition for adoption, a good understanding of potential information failures that limit farmers' adoption of available technologies is considered a key. This puts the focus on the transfer and the acquirement of new information through the networks. Since the 
adoption of new technologies presents learning and adaptational challenges for farmers, the theoretical approach of the papers builds on the role of the network as a learning organization.

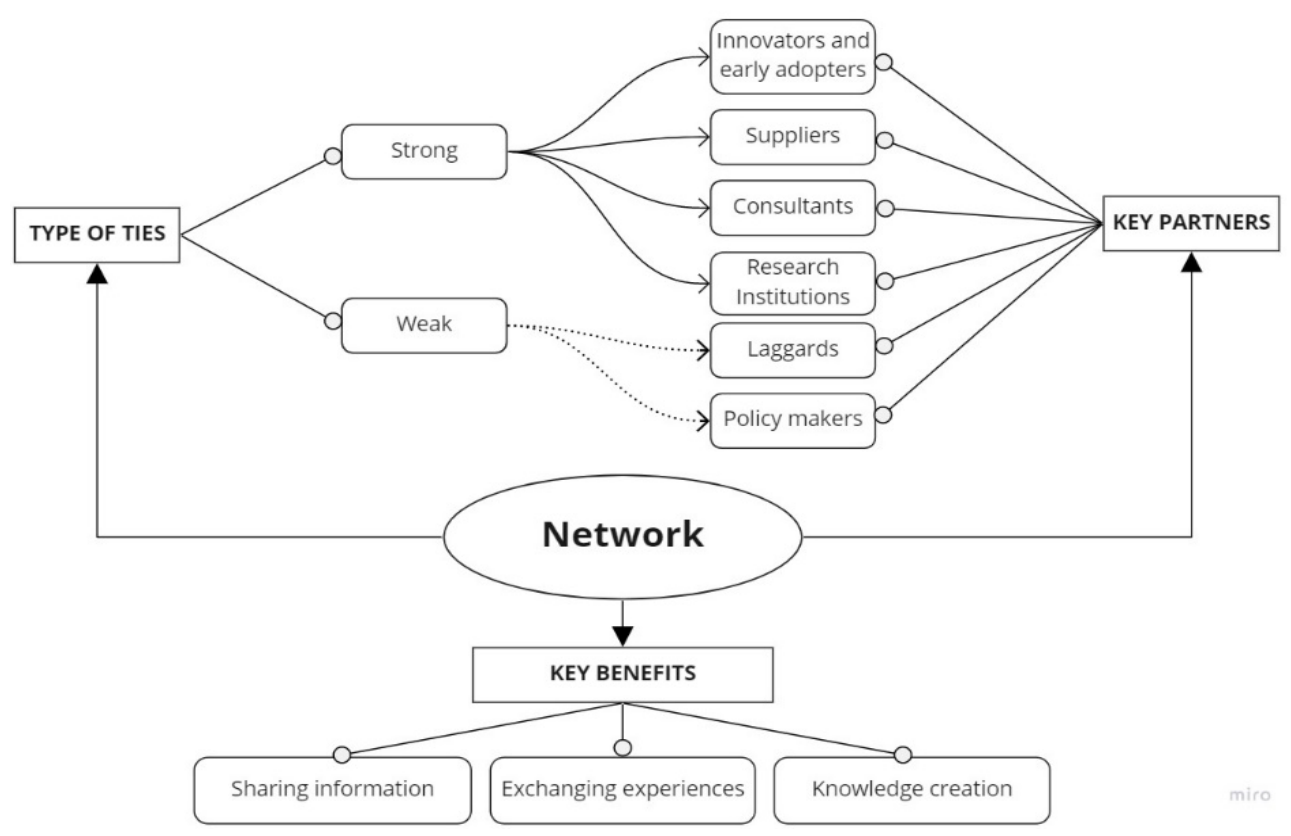

Figure 2 - Conceptual framework

The process, involving the capacity of an organization (firm) to learn from others, is also referred to as organizational learning within a network (Knight, 2002; Easterby-Smith et al., 2008). Networks are considered important sources of knowledge for firms (Powell, 1996; Maskell, 2001; Tallman et al., 2004). The diffusion of information and the subsequent adoption of innovation relies heavily on social relationships, particularly in agricultural management. The interactions of a variety of actors, and the subsequent emergent networks of information exchange, are fundamental in the adoption of innovative technologies. In fact, the structure of these networks can influence the advancement or weakening of technological change and, for this reason, is a central attribute to successful innovation systems (Klerkx et al., 2010; Spielman et al., 2011).

Based on the above framework, in the following subsections, we discuss the main aspects connected to the network dynamics that determine a successful adoption process of digital technology.

\subsection{Type of Ties}

Within the network, farmers build two different types of ties: Strong and Weak. Strong ties exist between close-knit members with frequent interactions, such as family members and closest friends. By contrast, weak ties are characterized by distant social relationships and infrequent interactions, which are commonly observed between acquaintances or strangers (Zorzi, 2019).

In this study, strong ties are established with similar individuals, such as innovative farmers, with whom the same issues of interest are shared and with whom a relationship of trust is built over time. However, a network characterized exclusively by the presence of strong ties could show a structural weakness, since the information between members with a strong tie could be redundant, considering the similarities between them (same interests, professions, 
or geographical location). On the contrary, including weak ties within the network could lead to greater contamination between different members, by providing non-redundant information, but also create crucial bridges through which information can move rapidly and widely in a network (Zhang et al., 2020).

\subsection{Key partners}

The study shows how farmers form strong ties with individuals from whom they can derive high-quality information about the technology. Farms connect with innovative farmers like them, with proven expertise in digital technologies. At the same time, farmers have a direct relationship with technology providers, who not only assist their proprietary technologies but also constantly update farmers on the newest technology on the market. In addition, farmers can also benefit from the assistance of IT consultants that work in partnership with clients, advising them on how to use information technology to meet their business objectives.

Farms also have a close collaboration with the research institutions, such as Universities, to carry out joint research projects on smart farming technologies (Eastwood et al., 2017). On the contrary, farmers have rare contact with the laggards, since they have no points in common with the latter. These results are in line with the work of Rose et al. (2021) which suggests that a multi-actor approach is necessary for the diffusion of digital technology.

Finally, even if the interviewees recognize the importance of the policies for the innovation, necessary to guarantee investment funds for the purchase of new technologies, farmers are not satisfied with current political support such as the access to the public funds, which is a challenging process.

\subsection{Key benefits}

Through the network, farmers can learn about new technologies, and by comparing themselves with the members of the network they get feedback on the use of technology. This also highlights the importance of the networks as "learning organizations" about the farming context, characterized by a weak organizational framework. In this study, we can define a network as a set of relationships, alliances, and other different forms of interaction with external sources of knowledge.

Within the network the actors can share different types of information about technologies: the interviewees share information about the novelty on the markets, and also about important fairs and events related to technology, in which they participated. During trade fairs, there is no physical distance between actors in the network; moreover, many actors meet at the same time. This creates specific conditions for the exchange of information and knowledge-building. Farms as visitors attend trade shows to learn about new solutions, suppliers, and products (Gopalakrishna \& Lilien, 1995) by interacting with products and prototypes, exhibitor staff, and other customers, visitors obtain tacit knowledge about market offerings that would otherwise be difficult to acquire (Borghini et al., 2006).

Sharing experiences and information leads to the acquisition of new knowledge about technology, and as a result, new business opportunities can open up. In line with the previous studies (Rothwell \& Dodgson, 1991; Edwards et al., 2005; Bentivoglio et al., 2016; Blanc et al., 2018), this research confirms that, also within the agri-food chain, farmers consider networks as ways to extend their innovative technological capabilities. 


\section{Concluding remarks}

The changes brought about by globalization and the digital economy are creating pressures on firms. Moreover, the fast development of digital technologies imposes an even faster pace of change at the organizational level. Some firms are more exposed to the necessity of adopting and successfully using digital technologies, while others are under less pressure. However, in the long run, no competitive firm can avoid the effect of digitalization.

The agri-food supply chain, and in particular the first step of farming, strongly characterized by traditional practices and by fragmentation, is still at the initial stage of digitalization. With this study, we aimed to enrich current knowledge on digital transformation in the agricultural sector and the role that networks play in this change. Specifically, we examined the type of networks that the farmer, considered as managers, interacts with and the type of information exchanged.

Our framework, emerging from our analysis and based on the model of the network as a learning organization, contributes to the literature by emphasizing the role of networks, which is necessary to boost and support the adoption of digital technologies and their use in the agri-food chain. Unlike previous research that focused on demographic variables related to the managers, such as age, gender, and education, our research tries to explore and highlight how the use of networks could enhance farmers 'managerial skills', namely those skills related to self-awareness, communication, and interpersonal capabilities. This is crucial for the digital transformation process.

In this sense, we underline the importance of the core belief of the manager and his/her ability to create networks as a factor that explains and justifies most of the strategic actions supporting the digital transformation process. Our study suggests that managers need to invest in forming the right attitude to digital technologies and collect information and knowledge by any means possible. The network of relationships is the most common and efficient way of pursuing these learning activities. Great attention must be put into the selection of the network members from which to be influenced. In particular, multi-actor innovation networks allow fostering interactions between actors for jointly solving agriculture-related challenges.

Constructing innovation networks generally involves attracting entrepreneurial members that act as champions, fostering linkages and cooperation, stimulating learning, and mobilizing adequate resources. From the literature, we learn that the digital transformation process is a never-ending and highly dynamic process whose success strongly depends on the digital strategy. In highly dynamic and continuous processes we believe that is important to have fixed and strong networks that act as support for proactive behavior. For this reason, the sharing of information through specialized networks should be enhanced to facilitate the collective learning process.

However, for many farmers, these technologies are hard to grasp: this is due to the limited access to training in digital technologies, the poor attainment of digital skilling, and the limited access to the opportunities that can be derived from possessing these skills. As is the case for all research, our study has a few limitations that should be taken into account when considering the reliability of the results obtained. This research provides a starting point that will assist in a further understanding of the technological change phenomenon.

\section{References}

Adnan, N., Nordin, S. M., Bahruddin, M. A., \& Tareq, A. H. (2019). A state-of-the-art review on facilitating sustainable agriculture through green fertilizer technology adoption: assessing farmers behavior. Trends in Food Science \& Technology, 86, 439-452. 
Ahuja, G. (2000). Collaboration networks, structural holes, and innovation: a longitudinal study. Administrative Science Quarterly, 45(3), 425-455.

Almeida, J. P. L. D., Farias, J. S., \& Carvalho, H. S. (2017). Drivers of the technology adoption in healthcare. BBR. Brazilian Business Review, 14(3), 336-351.

Avermaete, T., Viaene, J., Morgan, E. J., \& Crawford, N. (2003). Determinants of innovation in small food firms. European Journal of Innovation Management, 6(1), 8-17.

Avolio, G., Blasi, E., Cicatiello, C., \& Franco, S. (2014). The drivers of innovation diffusion in agriculture: evidence from Italian census data. Journal on Chain and Network Science, 14(3), 231-245. http://dx.doi.org/10.3920/JCNS2014.x009

Babbie, E. (2001). Content analysis. In The practice of social research (pp. 304-315).

Bandiera, O., \& Rasul, I. (2006). Social networks and technology adoption in northern Mozambique. Economic Journal, 116(514), 869-902.

Baregheh, A., Rowley, J., Sambrook, S., \& Davies, D. (2012). Innovation in food sector SMEs. Journal of Small Business and Enterprise Development, 19(2), 300-321.

Barnes, A. P., Soto, I., Eory, V., Beck, B., Balafoutis, A., Sánchez, B., Vangeyte, J., Fountas, S., van der Wal, T., \& Gómez-Barbero, M. (2019). Exploring the adoption of precision agricultural technologies: a cross regional study of EU farmers. Land Use Policy, 80, 163-174.

Bates, M. J. (1999). The invisible substrate of information science. Journal of the American Society for Information Science, 50(12), 1043-1050.

Becheikh, N., Landry, R., \& Amara, N. (2006). Lessons from innovation empirical studies in the manufacturing sector: A systematic review of the literature from 1993-2003. Technovation, 26(5-6), 644-664.

Beneito, P. (2003). Choosing among alternative technological strategies: an empirical analysis of formal sources of innovation. Research Policy, 32(4), 693-713.

Bentivoglio, D., Giampietri, E., \& Finco, A. (2016). The new EU innovation policy for farms and SMEs' competitiveness and sustainability: the case of Cluster Agrifood Marche in Italy. Quality - Access to Success, 17(1), 57-63.

Berta, W., Teare, G. F., Gilbart, E., Ginsburg, L. S., Lemieux-Charles, L., Davis, D., \& Rappolt, S. (2005). The contingencies of organizational learning in long-term care: factors that affect innovation adoption. Health Care Management Review, 30(4), 282-292.

Bitsch, V., \& Hogberg, M. (2005). Exploring horticultural employees' attitudes toward their jobs: A qualitative analysis based on Herzberg's theory of job satisfaction. Journal of Agricultural and Applied Economics, 37(3), 659-671.

Blanc, S., Lingua, F., Bioglio, L., Pensa, R. G., Brun, F., \& Mosso, A. (2018). Implementing participatory processes in forestry training using social network analysis techniques. Forests, 9(8), 463.

Bolfe, É. L., Jorge, L. A. D. C., Sanches, I. D. A., Luchiari Júnior, A., Costa, C. C., Victoria, D. D. C., Inamasu, R. Y., Grego, C. R., Ferreira, V. R., \& Ramirez, A. R. (2020). Precision and Digital Agriculture: Adoption of Technologies and Perception of Brazilian Farmers. Agriculture, 10(12), 653.

Borghini, S., Golfetto, F., \& Rinallo, D. (2006). Ongoing search among industrial buyers. Journal of Business Research, 59(10-11), 1151-1159.

Bozeman, B. (2000). Technology transfer and public policy: a review of research and theory. Research Policy, 29(4-5), 627-655. 
Bucci, G., Bentivoglio, D., Belletti, M., \& Finco, A. (2020). Measuring the farm's profitability after the adoption of Precision Agriculture Technologies: A case study research from Italy. Acta IMEKO, 9(3), 65.

Bucci, G., Bentivoglio, D., \& Finco, A. (2019). Factors affecting ICT adoption in agriculture: a case study in Italy. Calitatea, 20(S2), 122-129.

Bullinger, H. J., Auernhammer, K., \& Gomeringer, A. (2004). Managing innovation networks in the knowledge-driven economy. International Journal of Production Research, 42(17), 3337-3353.

Burla, L., Knierim, B., Barth, J., Liewald, K., Duetz, M., \& Abel, T. (2008). From text to codings: intercoder reliability assessment in qualitative content analysis. Nursing Research, 57(2), 113-117.

Cantner, U., \& Graf, H. (2011). 15 innovation networks: formation, performance and dynamics. Handbook on the economic complexity of technological change (366 p.).

Chavas, J. P. (2001). Structural change in agricultural production: economics, technology and policy. In Handbook of agricultural economics (Vol. 1, pp. 263-285).

Chen, C. (2020). Technology adoption, capital deepening, and international productivity differences. Journal of Development Economics, 143, 102388.

Cheong, H. J., \& Mohammed-Baksh, S. (2019). US consumer m-commerce involvement: using in-depth interviews to propose an acceptance model of shopping apps-based m-commerce. Cogent Business \& Management, 6(1), 1674077.

Chesbrough, H. (2012). Open innovation: Where we've been and where we're going. Research Technology Management, 55(4), 20-27.

Cho, H. J., \& Pucik, V. (2005). Relationship between innovativeness, quality, growth, profitability, and market value. Strategic Management Journal, 26(6), 555-575.

Cirani, C. B. S., \& Moraes, M. A. F. D. D. (2010). Inovação na indústria sucroalcooleira paulista: os determinantes da adoção das tecnologias de agricultura de precisão. Revista de Economia e Sociologia Rural, 48(4), 543-565.

Cochrane, W. W. (1958). Farm prices: myth and reality. Minneapolis: University of Minnesota Press.

Corsaro, D., Cantù, C., \& Tunisini, A. (2012). Actors' heterogeneity in innovation networks. Industrial Marketing Management, 41(5), 780-789.

Crossan, M. M., \& Apaydin, M. (2010). A multi-dimensional framework of organizational innovation: a systematic review of the literature. Journal of Management Studies, 47(6), 1154-1191.

Damanpour, F. (1992). Organizational size and innovation. Organization Studies, 13(3), 375-402.

De Faria, P., Lima, F., \& Santos, R. (2010). Cooperation in innovation activities: the importance of partners. Research Policy, 39(8), 1082-1092.

De Massis, A., Audretsch, D., Uhlaner, L., \& Kammerlander, N. (2018). Innovation with limited resources: management lessons from the German Mittelstand. Journal of Product Innovation Management, 35(1), 125-146.http://dx.doi.org/10.1111/jpim.12373

Wolf, P. D., McElwee, G., \& Schoorlemmer, H. (2007). The European farm entrepreneur: a comparative perspective. International Journal of Entrepreneurship and Small Business, 4(6), 679-692.

DePaolo, C. A., \& Wilkinson, K. (2014). Get your head into the clouds: using word clouds for analyzing qualitative assessment data. TechTrends, 58(3), 38-44. 
Desouza, K. C., \& Awazu, Y. (2006). Knowledge management at SMEs: five peculiarities. Journal of Knowledge Management, 10(1), 32-43.

Drejer, I., \& Jørgensen, B. H. (2005). The dynamic creation of knowledge: analysing public-private collaborations. Technovation, 25(2), 83-94.

Durst, S., Edvardsson, I. R., \& Bruns, G. (2013). Knowledge creation in small building and construction firms. Journal of Innovation Management, 1(1), 125-142.

Dziallas, M., \& Blind, K. (2019). Innovation indicators throughout the innovation process: an extensive literature analysis. Technovation, 80, 3-29. http://dx.doi.org/10.1016/j. technovation.2018.05.005

Easterby-Smith, M., Lyles, M. A., \& Tsang, E. W. (2008). Inter-organizational knowledge transfer: Current themes and future prospects. Journal of Management Studies, 45(4), 677-690.

Edwards, T., Delbridge, R., \& Munday, M. (2005). Understanding innovation in small and mediumsized enterprises: a process manifest. Technovation, 25(10), 1119-1127.

Elo, S., \& Kyngäs, H. (2008). The qualitative content analysis process. Journal of Advanced Nursing, 62(1), 107-115.

Elo, S., Kääriäinen, M., Kanste, O., Pölkki, T., Utriainen, K., \& Kyngäs, H. (2014). Qualitative content analysis: a focus on trustworthiness. SAGE Open, 4(1), 2158244014522633. http://dx.doi. org/10.1177/2158244014522633

Eastwood, C., Klerkx, L., \& Nettle, R. (2017). Dynamics and distribution of public and private research and extension roles for technological innovation and diffusion: case studies of the implementation and adaptation of precision farming technologies. Journal of Rural Studies, 49, 1-12. http://dx.doi.org/10.1016/j.jrurstud.2016.11.008

Eze, S., Duan, Y., \& Jackson, S. (2011, April). Understanding the dynamic process of emerging ICT adoption in UK service SMEs. In Proceeding of the 16th Annual Conference 2011 UK Academy for Information Systems.

Finco, A., Bentivoglio, D., \& Bucci, G. (2018). Lessons of innovation in the agrifood sector: Drivers of innovativeness performances. Economia Agro-Alimentare, (2), 181-192.

Fortuin, F. T., \& Omta, S. W. F. (2009). Drivers and barriers to innovation in the food processing industry continued: a comparison of the Netherlands and the Shanghai Region in China (No. 1017-2016-81623, pp. 483-498).

Frambach, R. T., \& Schillewaert, N. (2002). Organizational innovation adoption: a multi-level framework of determinants and opportunities for future research. Journal of Business Research, 55(2), 163-176.

Geiger, S. W., \& Cashen, L. H. (2002). A multidimensional examination of slack and its impact on innovation. Journal of Managerial Issues, 14, 68-84.

Geletkanycz, M. A., \& Hambrick, D. C. (1997). The external ties of top executives: Implications for strategic choice and performance. Administrative Science Quarterly, 42(4), 654-681. http://dx.doi.org/10.2307/2393653

Glanz, K., Rimer, B. K., \& Viswanath, K. (Eds.). (2008). Health behavior and health education: theory, research, and practice. John Wiley \& Sons.

Gopalakrishna, S., \& Lilien, G. L. (1995). A three-stage model of industrial trade show performance. Marketing Science, 14(1), 22-42. 
Graneheim, U. H., \& Lundman, B. (2004). Qualitative content analysis in nursing research: concepts, procedures and measures to achieve trustworthiness. Nurse Education Today, 24(2), 105-112.

Griliches, Z. (1957). Hybrid corn: an exploration in the economics of technological change. Econometrica, 25(4), 501-522.

Hagedoorn, J. (2002). Inter-firm R\&D partnerships: an overview of major trends and patterns since 1960. Research Policy, 31(4), 477-492.

Hambrick, D. C., \& Mason, P. A. (1984). Upper echelons: The organization as a reflection of its top managers. Academy of Management Review, 9(2), 193-206.

Hakansson, H. (Ed.). (2015). Industrial technological development (routledge revivals): a network approach. Routledge.

Hoffman, K., Parejo, M., Bessant, J., \& Perren, L. (1998). Small firms, R\&D, technology and innovation in the UK: a literature review. Technovation, 18(1), 39-55.

Hsieh, H. F., \& Shannon, S. E. (2005). Three approaches to qualitative content analysis. Qualitative Health Research, 15(9), 1277-1288.

Ibeh, K., \& Kasem, L. (2011). The network perspective and the internationalization of small and medium sized software firms from Syria. Industrial Marketing Management, 4O(3), 358-367.

Ingram, J., Dwyer, J., Gaskell, P., Mills, J., \& Wolf, P. (2018). Reconceptualising translation in agricultural innovation: A co-translation approach to bring research knowledge and practice closer together. Land Use Policy, 70, 38-51.

Jarillo, J. C. (1989). Entrepreneurship and growth: The strategic use of external resources. Journal of Business Venturing, 4(2), 133-147.

Kahan, D. (2013). Entrepreneurship in farming (Farm Management Extension Guide, No. 5). FAO.

Kashada, A., Ehtiwsh, E., \& Nakkas, H. (2020). The role of technology acceptance model (TAM) towards information systems implementation success: a meta-analysis. International Journal of Engineering Science, 9(1), 30-36.

Katz, M. L., \& Shapiro, C. (1986). Technology adoption in the presence of network externalities. Journal of Political Economy, 94(4), 822-841.

Klerkx, L., Aarts, N., \& Leeuwis, C. (2010). Adaptive management in agricultural innovation systems: The interactions between innovation networks and their environment. Agricultural Systems, 103(6), 390-400.

Knierim, A., Kernecker, M., Erdle, K., Kraus, T., Borges, F., \& Wurbs, A. (2019). Smart farming technology innovations-Insights and reflections from the German Smart-AKIS hub. NJAS Wageningen Journal of Life Sciences, 90, 100314.

Knight, P. (2002). A systemic approach to professional development: learning as practice. Teaching and Teacher Education, 18(3), 229-241.

Knudsen, M. P. (2007). The relative importance of interfirm relationships and knowledge transfer for new product development success. Journal of Product Innovation Management, 24(2), 117-138.

Kondracki, N. L., Wellman, N. S., \& Amundson, D. R. (2002). Content analysis: Review of methods and their applications in nutrition education. Journal of Nutrition Education and Behavior, 34(4), 224-230.

Kosior, K. (2018). Digital transformation in the agri-food sector: opportunities and challenges. Roczniki, XX(2), 98-106. 
Kraft, P. S., \& Bausch, A. (2018). Managerial social networks and innovation: a meta-analysis of bonding and bridging effects across institutional environments. Journal of Product Innovation Management, 35(6), 865-889.

Laperche, B. (2012). General presentation innovation processes: why institutions matter. Journal of Innovation Economics Management, (1), 3-11.

Lasagni, A. (2012). How can external relationships enhance innovation in SMEs? New evidence for Europe. Journal of Small Business Management, 50(2), 310-339.

Li, L., Su, F., Zhang, W., \& Mao, J. Y. (2018). Digital transformation by SME entrepreneurs: a capability perspective. Information Systems Journal, 28(6), 1129-1157.

Lindblom, J., Lundström, C., Ljung, M., \& Jonsson, A. (2017). Promoting sustainable intensification in precision agriculture: review of decision support systems development and strategies. Precision Agriculture, 18(3), 309-331.

Lin, F. J., \& Lin, Y. H. (2016). The effect of network relationship on the performance of SMEs. Journal of Business Research, 69(5), 1780-1784.

Majumdar, S. K. (1995). The determinants of investment in new technology: an examination of alternative hypotheses. Technological Forecasting and Social Change, 50(3), 235-247.

Maskell, P. (2001). Knowledge creation and diffusion in geographic clusters. International Journal of Innovation Management, 5(2), 213-237.

McElwee, G. (2006). The enterprising farmer: a review of entrepreneurship in agriculture. Journal of the Royal Agricultural Society of England, 167(9).

Michels, M., Bonke, V., \& Musshoff, O. (2019). Understanding the adoption of smartphone apps in dairy herd management. Journal of Dairy Science, 102(10), 9422-9434.

Mohr, L. B. (1969). Determinants of innovation in organizations. The American Political Science Review, 63(1), 111-126.

Moore, M. H. (1995). Creating public value: strategic management in government. Harvard University Press.

Mors, M. L. (2010). Innovation in a global consulting firm: When the problem is too much diversity. Strategic Management Journal, 31(8), 841-872.

Narula, R. (2004). R\&D collaboration by SMEs: new opportunities and limitations in the face of globalisation. Technovation, 24(2), 153-161.

Neuendorf, K. A. (2002). Defining content analysis. In Content analysis guidebook. Thousand Oaks, CA: Sage.

Nieto, M. J., \& Santamaría, L. (2007). The importance of diverse collaborative networks for the novelty of product innovation. Technovation, 27(6-7), 367-377.

Nooteboom, B. (1994). Innovation and diffusion in small firms: theory and evidence. Small Business Economics, 6(5), 327-347.

Ojala, A. (2009). Internationalization of knowledge-intensive SMEs: The role of network relationships in the entry to a psychically distant market. International Business Review, 18(1), 50-59.

Pérez-Castillo, R., García-Rodríguez de Guzmán, I., Caballero, I., \& Piattini, M. (2013). Software modernization by recovering web services from legacy databases. Journal of Software: Evolution and Process, 25(5), 507-533.

Phelps, C., Heidl, R., \& Wadhwa, A. (2012). Knowledge, networks, and knowledge networks: A review and research agenda. Journal of Management, 38(4), 1115-1166. 
Pignatti, E., Carli, G., \& Canavari, M. (2015). What really matters? A qualitative analysis on the adoption of innovations in agriculture. Agrárinformatika. Agrárinformatika Folyóirat, 6(4), 73-84.

Pittaway, L., Robertson, M., Munir, K., Denyer, D., \& Neely, A. (2004). Networking and innovation: a systematic review of the evidence. International Journal of Management Reviews, 5(3-4), 137-168.

Powell, W. W. (1996). Trust-based forms of governance. In Trust in organizations: Frontiers of theory and research (p. 51).

Ritter, T., \& Gemünden, H. G. (2003). Network competence: Its impact on innovation success and its antecedents. Journal of Business Research, 56(9), 745-755.

Ritter, T., \& Gemünden, H. G. (2004). The impact of a company's business strategy on its technological competence, network competence and innovation success. Journal of Business Research, 57(5), 548-556.

Robertson, M., Swan, J., \& Newell, S. (1996). The role of networks in the diffusion of technological innovation. Journal of Management Studies, 33(3), 333-359.

Rogers, E. M. (1962). Diffusion of innovativeness. New York: The Free Press of Glencoe.

Rogers, E. M. (1971). Social structure and social change. The American Behavioral Scientist, 14(5), 767-782.

Rogers, E. M. (2003), Diffusion of Innovations. New York: The Free Press.

Rose, D. C., Wheeler, R., Winter, M., Lobley, M., \& Chivers, C. A. (2021). Agriculture 4.0: Making it work for people, production, and the planet. Land Use Policy, 100, 104933.

Rosenberg, N., \& Landau, R. (Eds.). (1986). The positive sum strategy: harnessing technology for economic growth. National Academies Press.

Rothwell, R., \& Dodgson, M. (1991). External linkages and innovation in small and medium-sized enterprises. Research Management, 21(2), 125-138.

Schumpeter, J. A. (1982). The theory of economic development: an inquiry into profits, capital, credit, interest, and the business cycle (1912/1934). Transaction Publishers.

Shibusawa, S. (1998). Precision farming and terramechanics. In Proceedings of the 5th AsiaPacific Regional Conference of ISTVS (pp. 251-261).

Shikida, P. F. A., Azevedo, P. F., \& Freitas Vian, C. E. (2010). Uma análise das capacidades tecnológicas da agroindústria canavieira em Minas Gerais. Revista de Economia e Agronegócio, $8(2), 251-278$.

Souza Filho, H. M., Buainain, A. M., da Silveira, J. M. F. J., \& Vinholis, M. D. M. B. (2011). Condicionantes da adoção de inovações tecnológicas na agricultura. Cadernos de Ciência \& Tecnologia, 28(1), 223-255.

Spielman, D. J., Davis, K., Negash, M., \& Ayele, G. (2011). Rural innovation systems and networks: findings from a study of Ethiopian smallholders. Agriculture and Human Values, 28(2), 195-212.

Stock, G. N., Greis, N. P., \& Fischer, W. A. (2002). Firm size and dynamic technological innovation. Technovation, 22(9), 537-549.

Tallman, S., Jenkins, M., Henry, N., \& Pinch, S. (2004). Knowledge, clusters, and competitive advantage. Academy of Management Review, 29(2), 258-271. 
Touzard, J. M., Temple, L., Faure, G., \& Triomphe, B. (2015). Innovation systems and knowledge communities in the agriculture and agrifood sector: a literature review. Journal of Innovation Economics Management, (2), 117-142.

Tsai, W. (2001). Knowledge transfer in intraorganizational networks: effects of network position and absorptive capacity on business unit innovation and performance. Academy of Management Journal, 44(5), 996-1004.

Van de Vrande, V., De Jong, J. P., Vanhaverbeke, W., \& De Rochemont, M. (2009). Open innovation in SMEs: trends, motives and management challenges. Technovation, 29(6-7), 423-437.

Warriner, G. K., \& Moul, T. M. (1992). Kinship and personal communication network influences on the adoption of agriculture conservation technology. Journal of Rural Studies, 8(3), $279-291$.

Wendschlag, M. (2009). Handbook of new institutional economics.

Yin, R. K. (1989). Research design issues in using the case study method to study management information systems. In The information systems research challenge: qualitative research methods (Vol. 1, pp. 1-6). Boston: Harvard Business School.

Zeng, S. X., Xie, X. M., \& Tam, C. M. (2010). Relationship between cooperation networks and innovation performance of SMEs. Technovation, 30(3), 181-194.

Zhang, A. J., Matous, P., \& Tan, D. K. (2020). Forget opinion leaders: the role of social network brokers in the adoption of innovative farming practices in North-western Cambodia. International Journal of Agricultural Sustainability, 18(4), 1-19.

Zorzi, O. (2019). Granovetter (1983): the strength of weak ties: a network theory revisited. In Schlüsselwerke der Netzwerkforschung (pp. 243-246). Wiesbaden: Springer. 